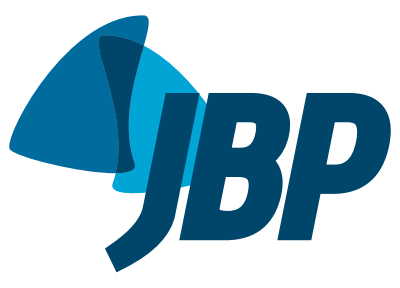

\title{
Cost analysis of nucleic acid amplification for diagnosing pulmonary tuberculosis, within the context of the Brazilian Unified Health Care System
}

\author{
Márcia Pinto1, Aline Piovezan Entringer¹, Ricardo Steffen², Anete Trajman²,3
}

1. Instituto de Saúde da Mulher, da Criança e do Adolescente Fernandes Figueira, Fundação Oswaldo Cruz, Rio de Janeiro (RJ) Brasil.

2. Programa de Pós-Graduação em Clínica Médica, Faculdade de Medicina, Universidade Federal do Rio de Janeiro, Rio de Janeiro (RJ) Brasil.

3. Montreal Chest Institute, McGill University, Montreal (OC) Canada.

Submitted: 4 December 2014.

Accepted: 14 July 2015.

Study carried out at the Instituto Nacional

\section{ABSTRACT}

We estimated the costs of a molecular test for Mycobacterium tuberculosisand resistance to rifampin (Xpert MTB/RIF) and of smear microscopy, within the Brazilian Sistema Único de Saúde (SUS, Unified Health Care System). In SUS laboratories in the cities of Rio de Janeiro and Manaus, we performed activity-based costing and micro-costing. The mean unit costs for Xpert MTB/RIF and smear microscopy were $\mathrm{R} \$ 35.57$ and $\mathrm{R} \$ 14.16$, respectively. The major cost drivers for Xpert MTB/RIF and smear microscopy were consumables/reagents and staff, respectively. These results might facilitate future costeffectiveness studies and inform the decision-making process regarding the expansion of Xpert MTB/RIF use in Brazil.

Keywords: Costs and cost analysis; Tuberculosis; Nucleic acid amplification techniques.

de Saúde da Mulher, da Criança e do

Adolescente Fernandes Figueira, Fundação

Oswaldo Cruz, Rio de Janeiro (RJ) Brasil.

Brazil is among the 22 countries with the highest tuberculosis burden. ${ }^{(1)}$ One of the major obstacles to controlling the disease is the delay in diagnosis. Smear microscopy is a routine test within the Brazilian Sistema Único de Saúde (SUS, Unified Health Care System); however, it has low sensitivity. ${ }^{(2)}$ Xpert $^{\circledR}$ MTB/RIF (Cepheid; Sunnyvale, CA, USA), which is performed in the GeneXpert ${ }^{\circledR}$ system (Cepheid), is a rapid molecular test for detecting Mycobacterium tuberculosis and its rifampin-resistant mutants. ${ }^{(3)}$ In 2010, Xpert $^{\circledR}$ MTB/RIF was recommended by the World Health Organization for initial diagnosis in patients with tuberculosis and suspected multidrug resistance or HIV infection. ${ }^{(4)}$ The accuracy of the test is high, ${ }^{(5)}$ and studies have demonstrated that it is cost-effective ${ }^{(6-8)}$ in other scenarios. In Brazil, Xpert ${ }^{\circledR}$ MTB/RIF was approved by the National Committee for Health Technology Incorporation in September of 2013 for use within the SUS. ${ }^{(9)}$

The objective of the present study was to estimate the unit cost of Xpert $^{\circledR}$ MTB/RIF, since it does not yet have a reference value on the SUS Sigtap unified pricing list of the System for the Management of the Pricing List of Procedures, Drugs, and OPM (orthoses, prostheses, and materials). In addition, we intended to contribute information to support other economic evaluations in this field.

This was a descriptive study, which conducted a partial economic evaluation to estimate the cost of performing
Xpert $^{\circledR}$ MTB/RIF and smear microscopy (Ziehl-Neelsen method) within the SUS, performed in parallel with a pilot study of implementation of GeneXpert ${ }^{\circledR}$ use for the diagnosis of pulmonary tuberculosis in two cities in Brazil. ${ }^{(10)}$ We selected two laboratories in the city of Rio de Janeiro, both of which are affiliated with the Secretaria Municipal de Saúde e Defesa Civil do Rio de Janeiro (SMSDC/RJ, Rio de Janeiro Municipal Department of Health and Civil Defense), and one laboratory in the city of Manaus, which is affiliated with the Secretaria de Estado de Saúde do Amazonas (SES/AM, Amazonas State Department of Health). This selection was based on the organization of the health care facility network, the level of decentralization, and the production output. In Rio de Janeiro, "laboratory 1 " is a polyclinic with a medium production output, and "laboratory 2 " is a family clinic with a small production output. In Manaus, the selected laboratory ("laboratory 3 ") is responsible for $71 \%$ of all smear microscopy examinations conducted in the city, it being considered to have a large production output.

We performed activity-based costing and micro-costing, on the basis of standard operating procedures for smear microscopy ${ }^{(2)}$ and for Xpert ${ }^{\circledR}$ MTB/RIF. ${ }^{(11)}$ The selected cost items were as follows: administrative costs (electricity, water, cleaning, and safety); staff costs, which included training (only for Xpert ${ }^{\circledR}$ MTB/RIF); laboratory consumable costs; and equipment costs. The Xpert ${ }^{\circledR}$ MTB/RIF cartridge cost R $\$ 20.46$ (US\$9.98), ${ }^{(12)}$ and the GeneXpert ${ }^{\circledR}$ system

\section{Correspondence to:}

Márcia Pinto.

Avenida Rui Barbosa, 716. Flamengo, CEP 22250-020, Rio de Janeiro, RJ, Brasil.

Tel.: 5521 2554-1915.

E-mail: mftpinto@gmail.com

Financial support: This study received financial support from the project known as Inovação para o Controle da Tuberculose (INCo-TB, Innovation for Tuberculosis Control), which is a partnership between the Brazilian National Tuberculosis Control Program and the Ataulpho de Paiva Foundation, with funding from the Bill and Melinda Gates Foundation. The funding sources did not affect the content of the present study or the decision to publish it. The authors take full responsibility for the study design and execution, as well as for the opinions expressed here. 
cost $\mathrm{R} \$ 34,850.00$ (US $\$ 17,000$ )-purchase prices for the study of implementation. ${ }^{(10)}$ The Brazilian National Ministry of Health is exempt from the costs of taxes and nationalization regarding the cartridges and GeneXpert ${ }^{\circledR}$.

Staff costs for Xpert ${ }^{\circledR}$ MTB/RIF use were calculated by a time and motion study undertaken at two separate time points in order to assess the learning curve of professionals: the first was fifteen days after GeneXpert ${ }^{\circledR}$ was installed in the laboratory, which is the time required for professionals to adapt to it; and the second was three months after the equipment was installed, at which point tests were routinely performed. This time was taken into account in the calculation of staff costs. Data collection for estimating the cost of smear microcopy occurred in a single step, because smear microscopy is a well-established procedure within the SUS. The administrative costs refer to the mean quarterly expenditures of the health care facilities where the laboratories are located and were apportioned according to floor space and production. Depreciation was applied when necessary, according to the useful life of the equipment. ${ }^{(13)}$ Costs of calibration and preventive/corrective maintenance on GeneXpert ${ }^{\circledR}$ were taken into account. ${ }^{(3)}$

The prices of the consumables were obtained from official sources, namely Comprasnet, Banco de Preços em Saúde, SMSDC/RJ, and SES/AM, and from the manufacturer (Cepheid). The mean cost of the tests is expressed in 2012 Brazilian reals. The costs of the cartridges and of GeneXpert ${ }^{\circledR}$ were converted from Brazilian reals to US dollars at a rate of $\mathrm{R} \$ 2.05=\mathrm{US} \$ 1.00$.

The study was approved by the Brazilian National Research Ethics Committee (Protocol no. 493/2011), by the SMSDC/RJ Research Ethics Committee (Protocol no. 445A/11), and by the Research Ethics Committee of the Fundação de Medicina Tropical de Manaus Dr. Heitor Vieira Dourado (Dr. Heitor Vieira Dourado Tropical Medicine Foundation of Manaus) in November of 2011.

We observed the production process of 230 smear microscopy examinations and 463 tests with Xpert $^{\circledR}$ MTB/RIF. There was a $30 \%$ reduction in mean completion time for Xpert ${ }^{\circledR}$ MTB/RIF between the first and second observations (9.87 $\mathrm{min}$ vs. $7.57 \mathrm{~min}$ ). The largest reductions were observed in laboratories 2 (54\%) and $3(35 \%)$. In the second observation, the mean completion time was $6.20 \mathrm{~min}$ (range, 4.87-7.53 $\mathrm{min}$ ) in laboratories 1 and 2 and 4.30 min (range, 3.53-5.07 min) in laboratory 3.

The mean cost of Xpert ${ }^{\circledR}$ MTB/RIF use was $\mathrm{R} \$ 35.57$ (range, $\mathrm{R} \$ 33.70-\mathrm{R} \$ 39.40$ ), and the mean cost of smear microscopy was $R \$ 14.16$ (range, $R \$ 11.30-R \$ 21.00$ ). The major cost drivers for Xpert MTB/RIF were consumables and reagents (62\%), especially the cartridges, whereas the major cost driver for smear microscopy was staff $(58 \%)$. There was great variability in staff costs between the two cities (Table 1 ). Therefore, the cost of two smear microscopy examinations, which are recommended by the Brazilian National Tuberculosis Control Program and required to achieve a sensitivity of $70 \%$, (2) represents $80 \%$ of the cost of an Xpert $^{\circledR}$ MTB/RIF test, which has a sensitivity of $88 \%$. ${ }^{(5)}$

During the data collection process, the production of Xpert ${ }^{\circledR}$ MTB/RIF tests increased relative to that of smears of the first sample, especially in RJ. The work hours of professionals remained unchanged, which suggests that the introduction of Xpert $^{\circledR}$ MTB/RIF represented a technical efficiency gain in the routine of the laboratories (Table 2).

Xpert ${ }^{\circledR}$ MTB/RIF is considered a promising technology for tuberculosis control because it provides fast, accurate, and cost-effective results. ${ }^{(5-8)}$ The present study conducted a partial economic evaluation, which describes exclusively the costs of performing the two technologies for the diagnosis of tuberculosis. Although we did not conduct a complete economic evaluation, the results detailed herein, together with comparative effectiveness data for the tests performed under routine conditions in the same cities where the pilot study was conducted, ${ }^{(10)}$ served as the basis for the estimates of cost-effectiveness ratios. ${ }^{(14)}$ We concluded that the cost of two smear microscopy examinations, which are usually required when tuberculosis is suspected, is close to (i.e., $80 \%$ of) the cost of an Xpert ${ }^{\circledR}$ MTB/RIF test.

One of the advantages of the present study was that it was carried out in parallel with the $\mathrm{Xpert}^{\circledR}$ MTB/RIF implementation study, ${ }^{(10)}$ which allowed us to observe the incorporation of the new technology into the use of resources and into the learning process of health professionals within the SUS. One study also estimated the cost of the test during a study of implementation, with results ranging from $\mathrm{R} \$ 46.40$ to $\mathrm{R} \$ 56.48$ (US $\$ 22.63$ to US\$27.55), much higher than ours. ${ }^{(8)}$ However, the price of the cartridge was higher than that used in the present study (R\$39.77-US\$19.40). The value added by

Table 1. Unit costs for Xpert ${ }^{\circledR}$ MTB/RIF and smear microscopy in the laboratories studied, Rio de Janeiro and Manaus (in Brazilian Reals, 2012). ${ }^{a}$

\begin{tabular}{lcccccc}
\multicolumn{1}{c}{ Cost item } & \multicolumn{3}{c}{ Smear microscopy } & \multicolumn{3}{c}{ Xpert MTB/RIF $^{\circ}$ Mab 3 } \\
\hline Staff costs & Lab 1 & Lab 2 & Lab 3 & Lab 1 & Lab 2 & Lab \\
Consumable and reagent costs & 5.18 & 3.76 & 15.87 & 3.71 & 3.01 & 13.27 \\
Equipment costs & 2.35 & 2.35 & 2.35 & 22.01 & 22.01 & 22.01 \\
Administrative costs & 1.34 & 0.85 & 0.97 & 4.07 & 3.96 & 2.42 \\
Unit cost & 2.51 & 2.81 & 2.14 & 4.18 & 4.03 & 2.04 \\
\hline & 11.38 & 9.77 & 21.33 & 33.97 & 33.01 & 39.74 \\
\hline
\end{tabular}

Lab: laboratory. ${ }^{a}$ Conversion rate used for the cartridge and GeneXpert ${ }^{\circledR}$ : US $\$ 1.00=\mathrm{R} \$ 2.05$ (2012). 
Table 2. Mean daily number of Xpert ${ }^{\circledR}$ MTB/RIF tests and smears of the first sample, produced in the laboratories studied, Rio de Janeiro and Manaus.

\begin{tabular}{cccc} 
Unit & $\begin{array}{c}\text { Smear } \\
\text { microscopy }\end{array}$ & $\begin{array}{c}\text { Xpert }^{\circ} \\
\text { MTB/RIF }\end{array}$ & \% increase \\
\hline Laboratory 1 & 10 & 13 & 30 \\
Laboratory 2 & 7 & 9 & 29 \\
Laboratory 3 & 31 & 34 & 10 \\
\hline
\end{tabular}

the other cost items was similar. Other studies reported costs ranging from $\mathrm{R} \$ 30.61$ (US\$14.93) to $\mathrm{R} \$ 54.41$ (US\$26.54). ${ }^{(15,16)}$ It is of note that all those studies were conducted in countries with different structures from that of the SUS, which limits the comparison.

The advantage of activity-based costing is the possibility of observing a significant number of tests, which makes it possible to identify a standard completion time and to perform a detailed inventory of the cost items. However, the method limits the possibilities of generalization, because of the organizational characteristics and the functioning of the laboratories studied.

The reduction in test completion time between the two observations was lower in laboratory 1 , since, during the second data collection time point, the trained technician was replaced with a less experienced one. In order to minimize the effects of this event, we observed a larger number of tests. It is believed that, with the incorporation of Xpert $^{\circledR}$ MTB/RIF into the routine of the laboratories, test completion time will decrease and production will increase. Therefore, it will be possible to increase technical efficiency and reduce the unit cost.

Among the limitations of the present study is the mean salary value, which does not reflect the Brazilian reality given the diversity of contractual arrangements in operation in the country. In order to minimize this diversity, we adopted the salaries of professionals affiliated with the state of AM and with the city of Rio de Janeiro, on the basis of different salary ranges. A second limitation relates to laboratory floor space, used for estimating cost per square meter. The physical structure varies among the facilities in terms of size and location; therefore, we included three laboratories with extremely different configurations, located in two Brazilian states.

The results of the present study might facilitate future cost-effectiveness studies and contribute to the establishment of a reference value on the Sigtap pricing list. However, since the adoption and use of technologies are dynamic and the results of the present study refer to the initial stage of the incorporation of Xpert $^{\circledR}$ MTB/RIF, it is important to observe whether there will be changes in its use.

In conclusion, the present study aimed to provide subsidies so that health care managers can identify the major cost drivers for Xpert $^{\circledR}$ MTB/RIF as well as possible gains in efficiency and effectiveness from its adoption. In this regard, our results might facilitate both programming and planning measures targeted at tuberculosis control in Brazilian cities.

\section{REFERENCES}

1. Brasil. Ministério da Saúde. Secretária de Vigilância à Saúde. O controle da tuberculose no Brasil: avanços, inovações e desafios Brasília: o Ministério. Boletim Epidemiológico. 2014;45(2)1-12.

2. Ministério da Saúde. Secretaria de Vigilância em Saúde. Manual nacional de vigilância laboratorial da tuberculose e outras micobactérias. Brasília: Ministério da Saúde; 2008

3. Cepheid. [homepage on the Internet] Sunnyvale (CA): Cepheid [cited 2014 Dec 3] The New GeneXpert@ System. New Systems. Same game-changing performance. Available from: http://www. cepheidinternational.com/systems-and-software/genexpert-system

4. World Health Organization. [homepage on the Internetl Geneva: WHO; [cited 2014 Dec 3]. WHO endorses new rapid tuberculosis test. Available from: http://www.who.int/mediacentre/news/ releases/2010/tb_test_20101208/en/index.html

5. Steingart KR, Sohn $H$, Schiller I, Kloda LA, Boehme CC, Pai M, et al. Xpert巴 MTB/RIF assay for pulmonary tuberculosis and rifampicin resistance in adults. Cochrane Database Syst Rev. 2013;1:CD009593. http://dx.doi.org/10.1002/14651858.cd009593.pub2

6. Choi HM, Miele K, Dowdy D, Shah M. Cost-effectiveness of Xpert巴 MTB/RIF for diagnosing pulmonary tuberculosis in the United States. Int J Tuberc Lung Dis. 2013;17(10):1328-35. http://dx.doi. org/10.5588/ijtld.13.0095

7. Menzies NA, Cohen T, Lin HH, Murray M, Salomon JA. Population health impact and cost-effectiveness of tuberculosis diagnosis with Xpert MTB/RIF: a dynamic simulation and economic evaluation PLoS Med. 2012:9(11):e1001347 http://dx.doi.org/10.1371/journal. pmed. 1001347

8. Vassal A, van Kampen S, Sohn H, Michael JS, John KR, den Boon $S$, et al. Rapid diagnosis of tuberculosis with the Xpert MTB/RIF assay in high burden countries: a cost-effectiveness analysis. PLoS Med. 2011;8(11):e1001120. http://dx.doi.org/10.1371/journal. pmed. 1001120

9. Brasil. Ministério da Saúde. Biblioteca Virtual em Saúde [homepage on the Internet]. Brasília: o Ministério; [cited 2014 Dec 3]. Portaria MS no. 48 de 10 de setembro de 2013. Available from: http://www.bvsms. saude.gov.br/bvs/saudelegis/sctie/2013/prt0048_10_09_2013.html

10. Durovni B, Saraceni V, van den Hof S, Trajman A, Cordeiro-Santos M Cavalcante $S$, et al. Impact of replacing smear microscopy with Xpert MTB/RIF for diagnosing tuberculosis in Brazil: a stepped-wedge cluster-randomized trial. PLoS Med. 2014;11(12):e1001766. http:// dx.doi.org/10.1371/journal.pmed.1001766

11. Cepheid. Manual Cepheid Rev C [CD-ROM]. Sunnyvale (CA): Cepheid; 2009

12. World Health Organization. [homepage on the Internet] Geneva: WHO; [cited 2013 Aug 4]. Tuberculosis Diagnostics - Xpert MTB/RIF Test. [Adobe Acrobat document, 2p.]. Available from: http://www. who.int/tb/publications/Xpert_factsheet.pdf

13. Ministério da Saúde. Secretaria de Ciência e Tecnologia Departamento de Tecnologia e Insumos Estratégicos. Diretrizes Metodológicas: estudos de avaliação econômica de tecnologias em saúde. Brasilia: Ministério da Saúde; 2009

14. Fundação Ataulpho de Paiva. Projeto Bill \& Melinda Gates. Rio de Janeiro: a Fundação; [cited 2013 Ago 04]. Estudos econômicos da incorporação do teste molecular GeneXpert ${ }^{\mathrm{TM}}$ MTB/Rif para o diagnóstico de tuberculose pulmonar no Sistema Único de Saúde. [Adobe Acrobat document, 36p.]. Available from: http:// www. fundacaoataulphodepaiva.com.br/2013/07/Relatoriotecnico_25042013.pdf

15. Shah M, Chihota V, Coetzee G, Churchyard G, Dorman SE. Comparison of laboratory costs of rapid molecular tests and conventional diagnostics for detection of tuberculosis and drugresistant tuberculosis in South Africa. BMC Infect Dis. 2013:13:352. http://dx.doi.org/10.1186/1471-2334-13-352

16. Meyer-Rath G, Schnippel K, Long L, MacLeod W, Sanne I, Stevens W, et al. The impact and cost of scaling up GeneXpert MTB/RIF in South Africa. PLoS One. 2012;7(5):e36966. http://dx.doi.org/10.1371/ journal.pone.0036966 


\section{ERRATUM}

Manuscript: Cost analysis of nucleic acid amplification for diagnosing pulmonary tuberculosis, within the context of the Brazilian Unified Health Care System

Publication: J Bras Pneumol. 2015;41(6):536-8.

DOI: http://dx.doi.org/10.1590/S1806-37562015000004524

On page 536 of the original publication, where it is written

Márcia Pinto, Anete Trajman, Ricardo Steffen, Aline Piovezan Entringer,

it should read

Márcia Pinto, Aline Piovezan Entringer, Ricardo Steffen, Anete Trajman. 